\title{
Phenological and Liver Antioxidant Profiles of Adult Nile Tilapia (Oreochromis niloticus) Exposed to Toxic Live Cyanobacterium (Microcystis aeruginosa Kützing) Cells
}

\author{
Hanan M. Khairy ${ }^{\mathrm{a}}$, Marwa A. Ibrahim ${ }^{\mathrm{b}, *}$, and Mai D. Ibrahem ${ }^{\mathrm{c}}$ \\ a Hydrobiology Laboratory, National Institute of Oceanography and Fisheries, \\ Alexandria, Egypt \\ b Department of Biochemistry, Faculty of Veterinary Medicine, Cairo University, \\ Giza, Egypt. Fax: +202-35725240. E-mail: marwa199@yahoo.com \\ c Department of Fish Diseases and Management, Faculty of Veterinary Medicine, \\ Cairo University, Giza, Egypt \\ * Author for correspondence and reprint requests \\ Z. Naturforsch. 67c, 620-628 (2012); received April 29, 2011/March 5, 2012
}

\begin{abstract}
Blue-green algae (cyanobacteria) constitute the greater part of the phytoplankton. Microcystis aeruginosa is amongst the most ubiquitously distributed cyanobacterial species, and almost invariably produces cyclic heptapeptide toxins called microcystins (MCs). The present study was designed to investigate the phenological and liver antioxidant profiles of the Nile tilapia Oreochromis niloticus chronically exposed to toxic live M. aeruginosa cells. Fish were grown in the absence and presence of $M$. aeruginosa in three different concentrations for seven days, and subsequently reared for another 30 days in the absence of the cyanobacteria. While cyanobacteria did not cause any fish mortality, there was a progressive development of yellowish discolouration in the livers of exposed fish. In the livers, the activities and levels of superoxide dismutase (SOD), lactate dehydrogenase (LDH), glutathione (GSH), and lipid peroxidation products like malondialdehyde (MDA) were elevated in response to the concentration of $M$. aeruginosa. Moreover, DNA fragmentation and DNA-protein crosslinks were measured. These parameters can thus be considered potential biomarkers for the fish exposure to $M$. aeruginosa. The present study sheds light on cyanobacterial blooms like health, environmental, and economic problem, respectively.
\end{abstract}

Key words: Cyanobacteria, Oreochromis niloticus, Oxidative Stress

\section{Introduction}

Eutrophication in water bodies is linked to anthropogenic influences such as climate change, poor agricultural practices, and the global nutrient run off from human waste disposal (Milinkovitch et al., 2011). Phytoplankton communities of eutrophic lakes are often dominated by cyanobacteria that can form dense blooms (Gragnani et al., 1999). Many cyanobacteria including the genera Microcystis and Anabaena produce toxic bioactive compounds like the hepatotoxic microcystin-LR and anatoxin-a (Fischer et al., 2000; El-Sheekh et al., 2010; Ibrahem et al., 2012). Microcystis spp. cyanobacteria grow in marine, brackish, and freshwater bodies (Fleming and Stephen, 2001). Blooming of toxic cyanobacteria has been detected in many ponds in Egypt (Shakweer and Gharib, 2005).

Cyanobacteria are harmful to both humans (Carmichael, 2001) and fish (Malbrouck and Kestemont, 2006). They cause direct intoxication of animals and humans through contact with water bloom or indirect poisoning by consumption of contaminated food (Mohamed et al., 2003). Besides being a source of nutrition for aquatic life, cyanobacterial blooms cause health hazards for terrestrial vertebrates. Toxic cyanobacteria in surface water ecosystems (Briand et al., 2003) cause hypoxia and clogging of gills of fish, and mortality in wild and cultured fish has been associated with mass occurrence of cyanobacteria. Uptake of cyanobacterial toxins by fish occurs primarily via oral ingestion of toxic cyanobacterial cells and, to a lesser or even negligible extent, from toxin uptake by the gill epithelium (Bury et al., 1995).

Microcystins are produced inside the cyanobacterial cells, and when cells lyse upon death the toxin is released into the water. Although microcystins can be broken down by some bacterial proteases, the toxin can persist for months 
or even years in natural water bodies, when bacteria producing such proteases are absent ( $\mathrm{Ra}$ pala, 2005).

Fish are exposed to the toxin either directly or by ingestion of cyanobacterial cells or a prey contaminated with cyanobacteria (Fischer et al., 2000). The liver functions in the biodegradation and biotransformation of toxins and exhibits an adaptive response. Microcystins are actively taken up by the liver of fish where they disrupt normal cellular activity by inhibiting all protein phosphatases (Meier-Abt, 2007). Inhibition of these enzymes in fish can ultimately result in widespread cellular death and loss of the liver structure (Malbrouck and Kestemont, 2006). Protein phosphatases are particularly important during fish embryonic development because they regulate critical developmental processes (Gotz, 2000).

Most of the previously conducted studies were restricted to the acute, rather than chronic exposure to toxin or bloom. In addition, the exposure routes in most previous studies did not realistically reflect environmentally relevant situations.

The aim of this study was to investigate the chronic exposure of Nile tilapia (Oreochromis niloticus) to M. aeruginosa with regard to phenological alterations and oxidative stress parameters.

\section{Material and Methods}

\section{Fish}

A total of 60 male Oreochromis niloticus of $(40.0 \pm 0.5) \mathrm{g}$ were netted, collected alive from an unpolluted semi-intensive fish farm, and transported in water tanks to the Fish Disease and Management Laboratory (FDML), Cairo University, Cairo, Egypt. Fish were acclimated to laboratory conditions during 2 weeks prior to the experiments. They were maintained in a tank containing chlorine-free aquarium water and acclimatized in a temperature-controlled environment, with a 12-h light/12-h dark cycle at $(26 \pm 2)^{\circ} \mathrm{C}$ and a pH value of about 7.0. Ammonia-nitrogen was monitored once a week; it was less than $0.5 \mathrm{mg} \mathrm{L}^{-1}$, and residual chloride was less than $0.01 \mathrm{mg} \mathrm{L}^{-1}$ (APHA, 1992). Fish were fed twice a day with a balanced commercial pelleted fish diet with 30\% protein (Zoocontrol Company, Cairo, Egypt) and starved $48 \mathrm{~h}$ before an experiment to clear their gut contents.

\section{Microcystis aeruginosa}

Microcystis aeruginosa was originally isolated, according to the procedure of Stein (1973), from a water sample from a River Nile channel near Tanta City, Egypt. One or two drops of the collected water sample were streaked on agar plates containing Allen and Stanier (1968) medium. The plates were then incubated for one week under controlled laboratory conditions [irradiance, $80 \mu \mathrm{mol} \mathrm{m} \mathrm{m}^{-2} \mathrm{~s}^{-1}$; temperature, $\left.(25 \pm 2){ }^{\circ} \mathrm{C}\right]$ in a culture chamber. The cultures of $M$. aeruginosa were grown axenically according to Venkataraman (1969). After one week, a single colony was transferred from an agar plate to an 1-L flask containing $500 \mathrm{~mL}$ of Allen and Stanier medium and incubated for 1-2 weeks. The cultures were then aerated with sterilized air and grown under the same conditions as during isolation. M. aeruginosa was identified according to Prescott (1978).

The growth of $M$. aeruginosa was measured by following the optical density at $750 \mathrm{~nm}$ according to Lerfort-Tran et al. (1988) and at the end of the exponential growth phase, the cells were harvested.

In a previous study by El-Sheekh et al. (2010), intracellular microcystin-LR (MC-LR) was quantified in $M$. aeruginosa during growth by high-performance liquid chromatography (HPLC) based on an MC-LR standard (Alexis Corporation, Lausen, Switzerland). The intracellular MC-LR concentration was $6.65 \mu \mathrm{g}(25 \mathrm{ml} \text { of cells })^{-1}$ which was equivalent to $65.5 \mu \mathrm{g}$ g dry weight ${ }^{-1}$, and the toxicity of MC-LR was confirmed in the brine shrimp (Artemia salina) bioassay according to Kiviranta et al. (1991).

\section{Experimental design}

Four groups of the previously acclimated $O$. niloticus, each containing 15 fish, were assigned for the experimental study. Three replicates, each consisting of 5 fish per group, were run. Each 5 fish were separately held in a glass aquarium containing $10 \mathrm{~L}$ of de-chlorinated water. A stock culture of $M$. aeruginosa containing $8 \cdot 10^{8}$ cells $\mathrm{mL}^{-1}$ was used to prepare cultures of $8 \cdot 10^{4}$ cells $\mathrm{mL}^{-1}$ (group 1 ), $16 \cdot 10^{4}$ cells $\mathrm{mL}^{-1}$ (group 2), and $24 \cdot 10^{4}$ cells $\mathrm{mL}^{-1}$ (group 3 ), respectively, in three aquaria for each concentration.

During the 7-d exposure trial, fish were dependent on $M$. aeruginosa as source of food, a fourth group was kept without any treatment, 
assigned as the control (C), and fed a balanced diet $(30 \%$ protein) throughout the test period. Except for siphoning off the faeces from the bottom of the jars, water was not changed but well aerated. By the end of one week, fish from each group were transferred separately to aquaria containing chlorine-free tap water and fed a fish diet $(30 \%$ protein) for $30 \mathrm{~d}$. The test was run in duplicate.

\section{Mortality, clinical, and post-mortem investigations}

All fish were monitored closely during the experimental period. Behavioural responses, clinical signs, and mortalities were recorded daily. Postmortem examination was carried out at the end of the experimental period according to Amlacher (1970).

\section{Organ samples}

At the end of the experimental period, fish were killed by a sharp blow on the head followed by cervical dislocation. Livers were removed immediately frozen in liquid nitrogen, and stored at $-80^{\circ} \mathrm{C}$ for further investigations. Liver homogenate was prepared in PBS (phosphate-buffered saline) using a glass homogenizer. The homogenates were centrifuged at $13,000 \times \mathrm{g}$ for $10 \mathrm{~min}$ at $4{ }^{\circ} \mathrm{C}$, and the supernatants were stored at $-80{ }^{\circ} \mathrm{C}$ until analysed.

\section{Determination of reduced glutathione (GSH) level}

GSH level was determined according to Ellman (1959). Briefly, liver samples were homogenized with $25 \%(\mathrm{v} / \mathrm{v})$ trichloroacetic acid (TCA) and centrifuged at 7,500 x $g$ for $10 \mathrm{~min}$. The supernatant $(50 \mu \mathrm{L})$ was mixed with $230 \mu \mathrm{L}$ of $0.8 \mathrm{M}$ Tris- $\mathrm{HCl}$ [tris(hydroxymethyl)aminomethane- $\mathrm{HCl}$ ], $0.02 \mathrm{M}$ EDTA (ethylenediaminetetraacetic acid), $\mathrm{pH} 8.9$, and $20 \mu \mathrm{L}$ of $0.01 \mathrm{M}$ DTNB (2,2'-dinitro-5,5'-dithiobenzoic acid). The reaction mixture was incubated for $5 \mathrm{~min}$ at room temperature, before the absorbance of the formed GSH-DTNB conjugate was determined at $412 \mathrm{~nm}$.

\section{Determination of lactate dehydrogenase (LDH) activity}

LDH activity was determined using a kit from Spectrum Diagnostics (Cairo, Egypt) according to the manufacturer's instruction.

\section{Determination of superoxide dismutase (SOD) acitivity}

SOD activity was determined according to the procedure described by Giannopolitis and Ries (1977). Briefly, $1 \mathrm{~mL}$ of $50 \mathrm{~mm}$ HEPES (2-[4-(2-hydroxyethyl)piperazin-1-yl]ethanesulfonic acid) buffer, $\mathrm{pH} 7.8$, was added to $30 \mu \mathrm{L}$ of $0.1 \mathrm{~mm}$ NaEDTA, $1 \mathrm{~mL}$ of $50 \mathrm{~mm} \mathrm{Na}_{2} \mathrm{CO}_{3}, 150 \mu \mathrm{L}$ of $10 \mathrm{~mm}$ methionine, $150 \mu \mathrm{L}$ of $63 \mu \mathrm{M}$ NBT (nitroblue tetrazolium), and $30 \mu \mathrm{L}$ of $1.3 \mu \mathrm{m}$ riboflavin. The total volume was made up to $3 \mathrm{~mL}$ with sample; then the absorbance was read at $560 \mathrm{~nm}$.

\section{Determination of lipid peroxidation}

Lipid peroxidation was measured as the amount of malondialdehyde (MDA) determined as the thiobarbituric acid reactive substance (TBARS) as described by Albro et al. (1986). In a centrifuge tube, $2.5 \mathrm{~mL}$ of $10 \%$ TCA were added to $0.5 \mathrm{~mL}$ of tissue homogenate and then put in a boiling water bath for $15 \mathrm{~min}$. Tubes were cooled under tap water and centrifuged at 2,500 x $g$ for $10 \mathrm{~min}$. Then, $2 \mathrm{~mL}$ of the supernatant were transferred to a test tube, and $1 \mathrm{~mL}$ of $0.67 \%$ thiobarbituric acid (TBA) was added. Tubes were shaken and kept in a boiling water bath for $20 \mathrm{~min}$, then cooled under tap water, and the optical density was read at $532 \mathrm{~nm}$ against the blank reagent TBA.

\section{Determination of protein}

Protein contents in the samples were determined by the method of Bradford (1976).

\section{DNA fragmentation assay}

The DNA fragmentation assay was conducted according to Sellins and Cohen (1987). Tissues were lysed in $1 \mathrm{~mL}$ buffer (10 mm Tris- $\mathrm{HCl}$, pH 7.4, 10 mм EDTA, 0.5\% Triton X-100). The pellets containing total intact DNA (designated P) and the supernatants containing smaller fragments of DNA (designated S) were treated separately with $0.5 \mathrm{~mL}$ of $25 \%$ TCA. Both sets were 
left overnight at $4{ }^{\circ} \mathrm{C}$, and precipitated DNA was collected by centrifugation. Each pellet was treated with $80 \mu \mathrm{L}$ of $5 \%$ TCA followed by heat treatment at $90{ }^{\circ} \mathrm{C}$ for $15 \mathrm{~min}$. One $\mathrm{mL}$ freshly prepared diphenylamine (DPA) reagent was added to each sample, tubes were allowed to stand overnight at room temperature, and the optical density was recorded at $600 \mathrm{~nm}$. Percentage DNA fragmentation was calculated as follows:

$\%$ DNA fragmentation $=[S /(S+P)] \cdot 100$, where $S$ is the optical density of the supernatant and $P$ the optical density of the pellet.

\section{DNA-protein cross-links}

DNA-protein cross-links were determined according to the procedure described by Zhitkovich and Costa (1992). Briefly, $1.5 \mathrm{~mL}$ of $2 \%$ sodium dodecyl sulfate (SDS) was added to $1.5 \mathrm{~mL}$ of liver homogenate. The mixture was kept frozen at $-20{ }^{\circ} \mathrm{C}$ for $12 \mathrm{~h}$. The sample was thawed and incubated at $65^{\circ} \mathrm{C}$ for $15 \mathrm{~min}$. Then, $1.5 \mathrm{~mL}$ of $200 \mathrm{~mm}$ $\mathrm{KCl}$ was added and the mixture cooled on ice for $5 \mathrm{~min}$ and centrifuged for $10 \mathrm{~min}$ at $150 \mathrm{x} \mathrm{g}$. The upper phase that contained free DNA was removed. The pellets, containing protein-bound DNA, were re-suspended in an equal amount of $\mathrm{KCl}$ and SDS, and precipitation was repeated three times. Proteinase $\mathrm{K}$ was added to digest the DNA-protein cross-links, and samples were incubated for $3 \mathrm{~h}$ at $50{ }^{\circ} \mathrm{C}$, then centrifuged for $10 \mathrm{~min}$ at $1,500 \times \mathrm{g}$. The supernatant containing bound DNA was removed. One $\mathrm{mL}$ of a solution containing $0.88 \mathrm{M}$ DPA in a solution containing $98 \%(\mathrm{v} / \mathrm{v})$ glacial acetic acid, $1.5 \%(\mathrm{v} / \mathrm{v})$ sulfuric acid, and $0.5 \%(\mathrm{v} / \mathrm{v})$ of $1.6 \%$ acetaldehyde solution was added to $0.5 \mathrm{~mL}$ of extracted DNA (free and bound). The absorbance was read at $578 \mathrm{~nm}$. The percentage of DNA-protein cross-links was calculated according to:

$\%$ DNA-protein cross-links $=[O D$ bound $/(O D$ free $+O D$ bound) $] \cdot 100$, where $O D$ bound is the optical density of protein-bound DNA in the pellet, and $O D$ free is the optical density of free DNA in the upper phase.

\section{Statistical analysis}

Values were expressed as mean $\pm \mathrm{SE}$ (standard error). The statistical analysis was performed using one way ANOVA (mean at significance level of $p \leq 0.05)$ according to Duncan (1955).

\section{Results}

Mortality, clinical, and post-mortem investigations

No mortality occurred in any of the aquaria throughout the test duration (30 days). The recorded abnormal manifestations were directly correlated with the concentration of $M$. aeruginosa cells. The fish in groups 2 and 3 (exposed to $16 \cdot 10^{4}$ and $24 \cdot 10^{4}$ cells $\mathrm{mL}^{-1}$, respectively, of M. aeruginosa) showed a gradual loss of appetite and lacked signs of escape reflex. No behavioural changes or any mortality was recorded in the control group throughout the period of the exposure. Behavioural, clinical, and post-mortem changes were noticeable among fish of groups 2 and 3, but not in fish of group 1 exposed to $8 \cdot 10^{4}$ cells $\mathrm{mL}^{-1}$. Post-mortem examination revealed obvious skin paleness in fish of groups 2 and 3. Visual inspection of the gastrointestinal tract at the end of the experiment revealed a progressive development of yellowish discolouration in the livers of treated fish.

\section{Determination of GSH level}

Fish exposed to different concentrations of $M$. aeruginosa cells had significantly elevated levels of GSH in comparison with the negative control group. This elevation was significant in groups 2 and 3 (Fig. 1).

\section{Determination of LDH activity}

The LDH activity was significantly increased in groups 1,2, and 3 compared to the control group (Fig. 2).

\section{Determination of SOD activity}

The SOD activity was significantly increased in groups 2 and 3 (Fig. 3).

\section{Determination of lipid peroxidation}

Significant changes were observed in the MDA level in exposed fish corresponding to the different concentrations of $M$. aeruginosa cells. The highest MDA level was detected in group 3 (Fig. 4). 


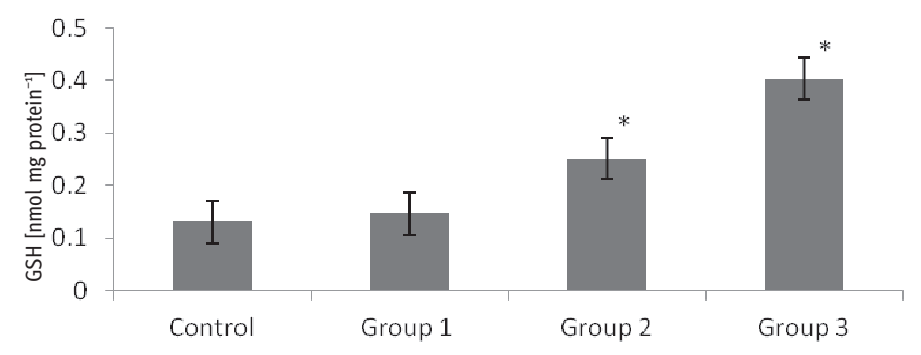

Fig. 1. Glutathione (GSH) level in livers of control fish and fish exposed to different concentrations of $M$. aeruginosa cells. The values are expressed as means \pm SE $(n=5)$. GSH levels are expressed as nmol mg protein ${ }^{-1}$. * Significantly different from the control group $(p \leq 0.05)$.

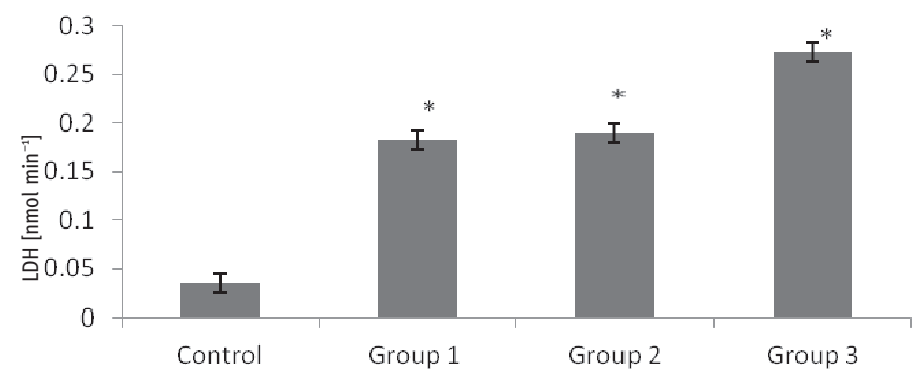

Fig. 2. Lactate dehydrogenase (LDH) activity in livers of control fish and fish exposed to different concentrations of $M$. aeruginosa cells. The values are expressed as means $\pm \mathrm{SE}(n=5)$. LDH activity is expressed as nmol min ${ }^{-1}$. * Significantly different from the control group $(p \leq 0.05)$.

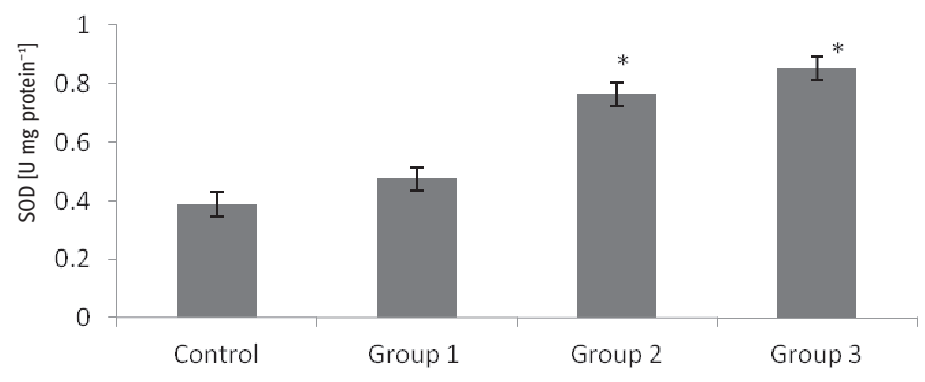

Fig. 3. Superoxide dismutase (SOD) activity in livers of control fish and fish exposed to different concentrations of $M$. aeruginosa cells. The values are expressed as means \pm SE $(n=5)$. SOD activity is expressed as $\mathrm{U} \mathrm{mg} \mathrm{protein}^{-1}$. * Significantly different from the control group $(p \leq 0.05)$.

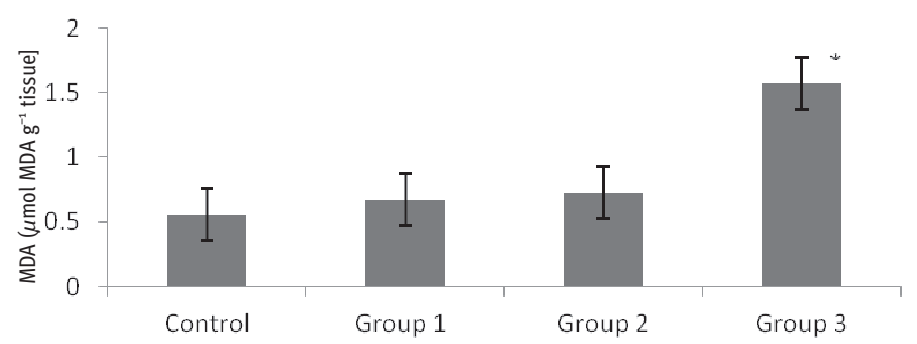

Fig. 4. Malondialdehyde (MDA) levels, as indicator of lipid peroxidation, in livers of control fish and fish exposed to different concentrations of $M$. aeruginosa cells. The values are expressed as means \pm SE $(n=5)$. Lipid peroxidation values are expressed as $\mu$ mol MDA g tissue ${ }^{-1}$. Significantly different from the control group $(p \leq 0.05)$. 


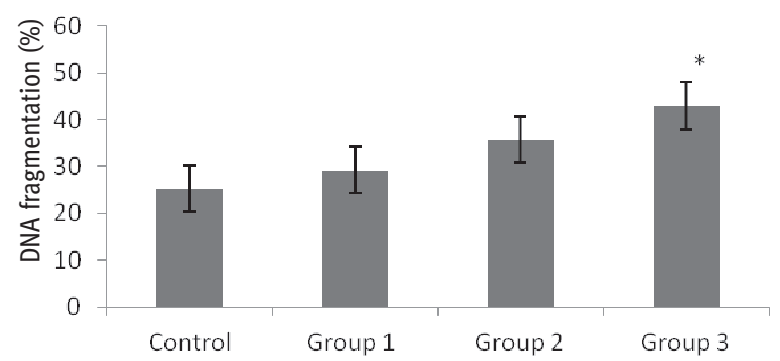

Fig. 5. DNA fragmentation assay in control fish and fish exposed to different concentrations of $M$. aeruginosa cells. The values are expressed as percentage of total DNA means $\pm \operatorname{SE}(n=5)$. *Significantly different from the control group $(p \leq 0.05)$.

\section{Determination of DNA fragmentation}

The DNA fragmentation percentage showed a significant elevation in group 3 in comparison to the negative control and other treated groups (Fig. 5).

\section{Determination of DNA-protein cross-links}

The percentage of DNA-protein cross-links was significantly increased in group 3 (Fig. 6).

\section{Discussion}

The population increase and the consequent intensification of agricultural and industrial activities have led to an increasing eutrophication of water bodies. Thus there are worldwide more frequent cyanobacterial blooms, and more fish are exposed to such blooms (Fleming and Stephen, 2001). Cyanobacteria can constitute part of the diet of several species of fish (Bowen, 1982), and high numbers of toxic Microcystis cells have been recorded in tilapia (Oreochromis niloticus L.) guts, which confirms that tilapia do graze on toxic cyanobacteria (Mohamed et al., 2003).

Very few studies have been conducted on the effects of Microcystis cells at concentrations being chronically toxic to $O$. niloticus $\mathrm{L}$. under laboratory conditions. Thus, we focused on studying the effects of exposing $O$. niloticus L. to water polluted with graded levels of $M$. aeruginosa for 30 days.

No mortality occurred in any of the fish groups during the entire test period. Clinical and behavioural abnormalities were observed in fish exposed to water containing $16 \cdot 10^{4}$ cells $\mathrm{mL}^{-1}$ and $24 \cdot 10^{4}$ cells $\mathrm{mL}^{-1}$ of $M$. aeruginosa. Gross morphological inspection of livers revealed a progressive development of yellowish discolouration in exposed fish. The results of the current study agreed with those of Tencalla and Dietrich (1997) on rainbow trout which were exposed to freezedried toxic cells of M. aeruginosa strain PCC 7806 at acutely toxic doses of $5700 \mu \mathrm{g}$ (g microcystin . $\mathrm{kg}$ body weight) ${ }^{-1}$. Jos et al. (2005) found that no $O$. niloticus died during exposure to intact and broken cyanobacterial cells containing $3230 \mu \mathrm{g}$ $\mathrm{g}$ microcystin-LR ${ }^{-1}$.

Microcystins in the cyanobacterial cells are responsible for the increase of cellular oxidative stress which subsequently can trigger apoptotic processes (Song et al., 2006; Zhang et al., 2008). Elevation of the GSH levels reflects stimulation of the detoxification metabolism as reported for aquatic organisms by Best et al. (2002).

There have been several laboratory and field studies documenting fish impairment associated with cyanobacterial blooms (Zimba et al., 2001; Malbrouck and Kestemont, 2006), and some of them have shown that impairment is a function of the dose and time of exposure to microcystins (Prieto et al., 2007; Zhang et al., 2008).

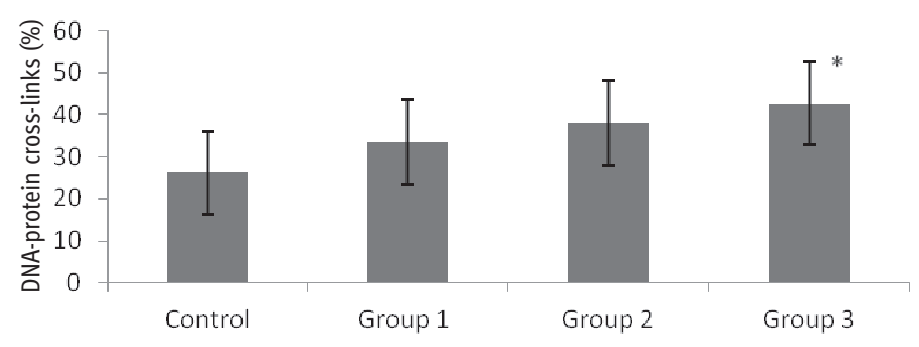

Fig. 6. DNA-protein cross-links in control fish and fish exposed to different concentrations of M. aeruginosa cells. The values are expressed as mean percentages $\pm \operatorname{SE}(n=5)$. *Significantly different from the control group $(p \leq 0.05)$. 
In the current study, the GSH levels were markedly elevated with increasing concentrations of M. aeruginosa cells (Fig. 1). An elevation of GSH and MDA levels, important biomarkers of oxidative stress, was detected in silver carp (Hypophthalmichthys molitrix Val.) grown in M. aeruginosa water blooms (Blaha et al., 2004). Zegura et al. (2006) verified an increase in the levels of reduced GSH during the exposure to MC-LR. Concomitant with this increase was the expression of glutamate-cysteine ligase (GCL), the rate-limiting enzyme of GSH synthesis, indicating an increased rate of the de novo synthesis of GSH. Li et al. (2008) reported an increase in GST (glutathione $S$-transferases) mRNA abundance in liver, kidney, and intestine of goldfish intraperitoneally injected with cyanobacterial crude extracts at doses of 50 and $200 \mu \mathrm{g} \mathrm{MC-LR} \mathrm{kg} \mathrm{body} \mathrm{weight}{ }^{-1}$.

Exposure of fish to cyanobacterial bloom induced DNA damage accompanied by an increased production of reactive oxygen species (ROS) and elevated LDH activity in the liver (Fig. 2).

The lipid peroxidation level was significantly increased only in group 3 (Fig. 4). This process of lipid peroxidation is controlled by an efficient cellular system involving SOD (Shika, 1996), which ensures the maintenance of cell integrity, optimum metabolism, and functional performance (Ernster, 1993). Changes in the levels of SOD were detected in fish exposed to different concentrations of $M$. aeruginosa cells such that the activ-

Albro P. W., Corbett J. T., and Schroeder J. L. (1986), Application of the thiobarbiturate assay to the measurement of lipid peroxidation products in microsomes. J. Biochem. Biophys. Methods 13, 185-194.

Allen M. M. and Stanier S. T. (1968), Selective isolation of blue-green algae from water and soil. J. Microbiol. 51, 302.

American Public Health Association (APHA) (1992), Standard Methods for the Examination of Water and Waste Water, 18th ed. Academic Press, Washington, DC, pp. 214-218.

Amlacher E. (1970), Text Book of Fish Disease. T. F. H. Publication, Neptune, NJ, USA, pp. 117-135.

Best J. H., Pflugmacher S., Wiegand C., Eddy F. B., Metcalf J. S., and Codd G. A. (2002), Effects of enteric bacterial and cyanobacterial lipopolysaccharides, and of microcystin-LR, on glutathione $S$-transferase activities in zebra fish (Danio rerio). Aquat. Toxicol. 60, $223-231$. ity of SOD increased from group 1 to 3 (Fig. 3). SOD is inducible in mammals, plants, and microorganisms, and the level of the enzyme increases with an increased need of protection against ROS production (Fridovich, 1986).

DNA damage caused by oxidative stress was assessed by the DNA fragmentation assay using the DPA method. The magnitude of DNA fragmentation was a function of the concentration of the cyanobacteria that the fish had been exposed to (Fig. 5). The induction of DNA fragmentation has been explained by a genotoxic effect of MCLR that may trigger apoptosis by endonuclease activation (Chen et al., 2005).

Proteins interacting with specific DNA sequences to turn genes on or off, i.e. transcriptional regulators (Hunter and Karin, 1992), can lead to deletion of DNA sequences during DNA replication which may cause cell death if the cross-link is not repaired (Tsapakos et al., 1981). DNA protein cross-linkage was significantly elevated in group 3 (Fig. 6). These results agree with those of Leao et al. (2008) who reported an elevation in DNA protein cross-links in polychaetes treated with microcystins.

The current study recorded potentially cumulative adverse effects (increases in SOD, LDH, GSH, and MDA) of increasing concentrations of toxic live M. aeruginosa cells on $O$. niloticus. These parameters can thus be considered potential biomarkers for exposure of fish to M. aeruginosa.
Blaha L., Kopp R., Simkova M., and Mares J. (2004), Oxidative stress biomarkers are modulated in silver carp (Hypophthalmichthys molitrix) exposed to microcystin-producing cyanobacterial water bloom. Acta Vet. Brno 73, 477-482.

Bowen S. H. (1982), Feeding and digestion and growthqualitative considerations. In: The Biology and Culture of Tilapias (Pullin R. S. V. and Lowe-McConnell R. H., eds.). International Center for Living Aquatic Resources Management (ICLARM), Manila, pp. 41-156.

Bradford M. M. (1976), A rapid and sensitiv method for the quantitation of microgram quantities of protein utilizing the principle of protein-dye binding. Anal. Biochem. 72, 248-254.

Briand J. F., Jacquet S., Bernard C., and Humbert J. F. (2003), Health hazards for terrestrial vertebrates from toxic cyanobacteria in surface water ecosystems. Vet. Res. 34, 361-377. 
Bury N. R., Eddy F. B., and Codd G. A. (1995), The effects of the cyanobacterium Microcystis aeruginosa, the cyanobacterial hepatotoxin microcystin-LR, and ammonia on growth rate and ionic regulation of brown trout. J. Fish Biol. 46, 1042-1054.

Carmichael W. W. (2001), Health effects of toxin-producing cyanobacteria: "The cyano HABs". Hum. Ecol. Risk Assess. 7, 1393-1407.

Chen T., Wang Q., Cui J., Yang W., Shi Q., Hua Z., Ji J., and Shen P. (2005), Induction of apoptosis in mouse liver by microcystin-LR. Mol. Cell. Proteomics 4, 958-974.

Duncan D. B. (1955), Multiple range and multiple (F) tests. Biometrics 11, 1-2.

Ellman G. L. (1959), Tissue sulfhydryl groups. Arch. Biochem. Biophys. 82, 70-77.

El-Sheekh M. M., Khairy H. M., and El-Shenody R. A. (2010), Allelopathic studies on the blue green alga (cyanobacterium) Microcystis aeruginosa. Allelopathy J. 26, 275-290.

Ernster L. (1993), Lipid peroxidation in biological membrane: mechanisms and implications. In: Active Oxygen, Lipid Peroxides and Antioxidant (Yagi K., ed.). CRC Press, Boca Raton, FL, USA, pp. 1-38.

Fischer W. J., Hitzfeld B. C., Tencalla F., Erifsson J. E., Mikhailov A., and Dietrich D. R. (2000), MicrocystinLR toxicodynamics, induced pathology, and immunohistochemical localization in livers of blue-green algae exposed rainbow trout (Oncorhynchus mykiss). Toxicol. Sci. 54, 365-373.

Fleming L. E. and Stephen W. (2001), Report to the Florida Harmful Algal Bloom Taskforce: Blue Green Algae, their Toxins and Public Health Issues. Marine and Freshwater Biomedical Sciences Center, University of Miami, Miami, FL, USA.

Fridovich I. (1986), Biological effects of superoxide radical. Arch. Biochem. Biophys. 247, 1-11.

Giannopolitis C. N. and Ries S. K. (1977), Superoxide dismutases: II. Purification and quantitative relationship with water-soluble protein in seedlings. Plant Physiol. 59, 315-318.

Gotz J. (2000), Distinct role of protein phosphatase $2 \mathrm{~A}$ subunit $\mathrm{C} \alpha$ in the regulation of E-cadherin and $\beta$-catenin during development. Mech. Dev. 93, 83-93.

Gragnani A., Scheffer M., and Rinaldi S. (1999), Topdown control of cyanobacteria: a theoretical analysis. Am. Nat. 153, 59-72.

Hunter T. and Karin M. (1992), The regulation of transcription by phosphorylation. Cell 70, 375-387.

Ibrahem M. D., Khairy H. M., and Ibrahim M. A. (2012), Laboratory exposure of Oreochromis niloticus to crude microcystins (containing microcystin-LR) extracted from Egyptian locally isolated strain ( $\mathrm{Mi}$ crocystis aeruginosa Kützing) L: Biological and biochemical studies. Fish Physiol. Biochem. 38, 899-908.

Jos A., Pichardo S., Prieto A. I., Repetto G., Carmen M. V., Moreno I., and Camean A. M. (2005), Toxic cyanobacterial cells containing microcystins induce oxidative stress in exposed tilapia fish (Oreochromis sp.) under laboratory conditions. Aquat. Toxicol. 72, $261-271$.

Kiviranta J., Saario E., and Neimela S. I. (1991), Toxicity of planktonic cyanobacteria (blue-green algae) to mosquito larvae. Planta Med. (Suppl.) 57, 21-22.
Leao J. C., Geracitano L. A., Monserrat J. M., Amado L. L., and Yunes J. S. (2008), Microcystin-induced oxidative stress in Laeonereis acuta (Polychaeta, Nereididae). Mar. Environ. Res. 66, 92-94.

Lerfort-Tran M., Pouphile M., Spath S., and Packer L. (1988), Cytoplasmic membrane changes during adaptation of the fresh water cyanobacterium Synechococcus 6311 to salinity. Plant Physiol. 87, 767-775.

Li G., Xie P., Fu J., Hao L., Xiong Q., and Li H. (2008), Microcystin-induced variations in transcription of GSTs in an omnivorous freshwater fish, goldfish. Aquat. Toxicol. 88, 75-80.

Malbrouck C. and Kestemont P. (2006), Effects of microcystins on fish. Environ. Toxicol. Chem. 25, 295-301.

Meier-Abt F. (2007), The organic anion transport polypeptide $1 \mathrm{~d} 1$ (Oatp1 d1) mediates hepatocellular uptake of phalloidin and microcystin into skate liver. Toxicol. Appl. Pharmacol. 218, 274-279.

Milinkovitch T., Ndiaye T., Sanchez W., Le Floch S., and Guyon H. T. (2011), Liver antioxidant and plasma immune responses in juvenile golden grey mullet (Liza aurata) exposed to dispersed crude oil. Aquat. Toxicol. 101, 155-164.

Mohamed Z. A., Carmichael W. W., and Hussein A. A. (2003), Estimation of microcystins in the fresh water fish Oreochromis niloticus in an Egyptian fish farm contaning a microcystis bloom. Environ. Toxicol. 18, $137-141$.

Prescott G. W. (1978), How to Know the Fresh Water Algae. Brown Company Publishers, Dubuque, IA, USA, pp. 12-267.

Prieto A. I., Pichardo S., Jos A., Moreno I., and Camean A. M. (2007), Time dependent oxidative stress response after acute exposure to toxic cyanobacterial cells containing microcystins in tilapia fish (Oreochromis niloticus) under laboratory conditions. Aquat. Toxicol. 84, 337-345.

Rapala J. (2005), Paucibacter toxinivorans gen. nov., sp. nov., a bacterium that degrades cyclic cyanobacterial hepatotoxins microcystins and nodularin. Int. J. Syst. Evol. Microbiol. 55, 1563-1568.

Sellins K. S. and Cohen J. J. (1987), Gene induction by gamma-irradiation leads to DNA fragmentation in lymphocytes. J. Immunol. 139, 3199.

Shakweer L. M. and Gharib S. M. (2005), Chemical and biological conditions during the harmful algal bloom in the Nozha Hydrodrome water during autumn 2002. Proceedings of the 15th International Conference on "Environmental Protection is a Must", Alexandria, Egypt, 3-5 May, 2005.

Shika S. C. (1996), Oxidative stress and role of antioxidants in normal and abnormal sperm function. Front. Biosci. 1, 78-80.

Song W., de la Cruz A. A., Rein K., and O'Shea K. E. (2006), Ultrasonically induced degradation of microcystin-LR and -RR: Identification of products, effect of $\mathrm{pH}$, formation and destruction of peroxides. Environ. Sci. Technol. 40, 3941-3946.

Stein J. R. (1973), Handbook of Phycological Methods, Culture Methods and Growth Measurements. Cambridge University Press, London.

Tencalla F. G. and Dietrich D. (1997), Biochemical characterization of microcystin toxicity in rainbow trout (Oncorhynchus mykiss). Toxicon 34, 583-595. 
Tsapakos M. J., Hampton T. H., and Jennette K. W. (1981), The carcinogen chromate induces DNA cross-links in rat liver and kidney. J. Biol. Chem. 256, 3623-3626.

Venkataraman G. S. (1969), The Cultivation of Algae. Indian Council of Agricultural Research, New Delhi.

Zegura B., Lah T. T., and Filipic M. (2006), Alteration of intracellular GSH levels and its role in microcystin-LR-induced DNA damage in human hepatoma HepG2 cells. Mutat. Res. 611, 25-33.

Zhang H., Zhang J., Chen Y., and Zhu Y. (2008), Microcystin R.R. induces apoptosis in fish lymphocytes by generating reactive oxygen species and causing mitochondrial damage. Fish Physiol. Biochem. 34, 307-312.

Zhitkovich A. and Costa M. (1992), A simple, sensitive assay to detect DNA-protein cross links in intact cells and in vivo. Carcinogenesis 13, 1485-1489.

Zimba P. V., Khoo L., Gaunt P., Carmichael W. W., and Brittain S. (2001), Confirmation of catfish, Ictaluruspumctatus (Rafinesque), mortality from Microcystis toxins. J. Fish Dis. 24, 41-47. 